\title{
Pangan Fungsional Berbasis Susu dan Produk Turunannya
}

\author{
[Milk based Functional Food and Its Derivative Products]
}

\author{
Fitri Suciati $^{1 *)}$ dan Laras Sirly Safitri ${ }^{2)}$ \\ 1,2 Prodi Agroindustri, Jurusan Agroindustri, Politeknik Negeri Subang, Subang, Jawa Barat \\ * Email korespondensi : fitrisuciati@polsub.ac.id \\ Dikirim 2021-01-01 \\ Direvisi 2021-01-26 \\ Diterima 2021-04-22
}

\begin{abstract}
Milk is food that contains complete nutrients that are consumed by various groups. Milk contains macronutrients such as protein, fat and carbohydrates as well as micronutrients such as vitamins and minerals and other components that are useful for human nutritional and health needs. Apart from containing micro and macronutrients, milk and its derivative products also contain bioactive components that have certain physiological functions that are beneficial to health, which are called Functional Foods. Milk-based functional food and its derivatives have bioactive components such as bioactive peptides, prebiotics, probiotics, conjugated linoleic acid (CLA) and several other bioactive components. Milk and its derivative products such as cheese, yogurt, kefir, and other derivative products have the potential to be developed. The development of milk-based food into functional food is expected to reduce the risk of degenerative diseases such as obesity, coronary heart disease, hypertension and cancer.

Keywords: Bioactive Component, Funtional Foods, Milk, Milk-Derivied Products.
\end{abstract}

ABSTRAK

Susu merupakan pangan hasil ternak yang memiliki kandungan nutrien yang lengkap yang dikonsumsi oleh berbagai kalangan. Susu mengandung makronutrien seperti protein, lemak dan karbohidrat serta mikronutrien seperti vitamin dan mineral dan komponen lainnya yang bermanfaat bagi pemenuhan kebutuhan gizi dan kesehatan manusia. Selain mengandung mikro dan makronutrien, susu dan produk turunannya juga mengandung komponen bioaktif yang memiliki fungsi fisiologis tertentu yang bermanfaat untuk kesehatan, yang disebut dengan pangan fungsional. Pangan fungsional berbasis susu dan turunannya memiliki komponen bioaktif seperti bioaktif peptida, prebiotik, probiotik, conjugated linoleic acid (CLA) dan beberapa komponen bioaktif lainnya. Susu dan produk turunannya seperti keju, yogurt, kefir, dan produk turunan lainnya potensial untuk dikembangkan. Pengembangan pangan berbasis susu menjadi pangan fungsional diharapkan dapat menjadi pilihan konsumsi susu dan memberikan manfaat dalam menurunkan jumlah resiko penyakit degeneratif seperti obesitas, jantung koroner, hipertensi dan kanker.

Kata kunci: Komponen Bioaktif, Pangan Fungsional, Produk Turunan Susu, Susu.

\section{Pendahuluan}

Kemajuan teknologi dan peningkatan kesejahteraan cenderung merubah pola hidup masyarakat yang mendorong pada rendahnya aktivitas fisik dan pola konsumsi pangan yang buruk. Perubahan pola hidup ini menyebabkan turunnya kualitas hidup serta pemeliharaan kesehatan yang berakibat pada peningkatan penyakit degeneratif seperti diabetes, obesitas, penyakit kardiovaskular dan penyakit degeneratif lainnya. Salah satu cara untuk mengatasi atau mencegah peningkatan penyakit degeneratif adalah dengan cara mengonsumsi pangan fungsional.

Pangan fungsional adalah pangan yang mengandung satu atau lebih komponen fungsional yang berdasarkan kajian ilmiah mempunyai fungsi fisiologis tertentu, terbukti tidak membahayakan dan bermanfaat bagi kesehatan (Badan Pengawas Obat dan Makanan, 2005). Pangan fungsional juga dikenal sebagai nutrasetikal, nutraseutikal didefinisikan sebagai suatu nutrisi yang bermanfaat dalam menjaga kesehatan dan mencegah timbulnya suatu penyakit (Azura et al., 2019). Pangan fungsional memiliki komponen senyawa bioaktif yang memiliki fungsi tertentu yang memiliki fungsi atau manfaat fisiologis dan medis. Pangan fungsional memiliki manfaat untuk pertumbuhan dan perkembangan janin pada fase awal, memelihara kesehatan tubuh, menurunkan obesitas dan resiko penyakit kronis (European Commisson, 2010).

Salah satu pangan hasil hewani yang banyak dikonsumsi dan bergizi tinggi adalah susu dan produk turunannya, seperti keju, krim, yogurt, kefir serta produk olahan susu lainnya. Susu dan produk turunannya mengandung senyawa bioaktif seperti peptida bioaktif, protein, mineral, serat pangan yang 
ditambahkan dan vitamin yang berfungsi sebagai komponen senyawa bioaktif. Protein susu tersusun atas kasein, protein whey, imonuglobulin dan laktoferin. Komponen bioaktif dalam pangan berbasis susu seperti kasein, protein whey dan turunannya termasuk beberapa peptida yang memiliki aktivitas antihipertensi dan beberapa efek bioaktif seperti laktoferin, laktoperoksidase yang memiliki efek antimikroba, dan perbaikan jaringan tubuh (Playne et al., 2003). Konsumsi susu di Indonesia dari tahun ke tahun terus mengalami kenaikan. Menurut data Susesnas tahun 1993-2018 konsumsi susu sapi semakin meningkat dari tahun ke tahun dengan rata-rata pertumbuhan konsumsi susu murni sebesar 0,20 liter/kapita/tahun (Kementerian Pertanian, 2019). Hal ini menunjukkan adanya kesadaran masyarakat dalam mengkonsumsi susu. Sinergitas antara ilmu pengetahuan dan pengembangan produk pangan sangat penting guna memberikan manfaat bagi kesehatan. Selain itu dengan meningkatnya kesadaran masyarakat dalam mengkonsumsi susu, susu dan produk turunannya diharapkan dapat dikembangkan menjadi pangan fungsional.

\section{Produk Susu dan Turunannya sebagai Pangan Fungsional}

Susu merupakan bahan pangan yang hampir sempurna yang didefinisikan sebagai sekresi dari kelenjar susu dari mamalia. Susu yang biasa dikonsumsi diantaranya susu sapi, kambing dan kerbau. Berikut ini merupakan komposisi kimia beberapa mamalia pada Tabel 1:

Tabel 1. Komposisi Kimia Beberapa Mamalia

\begin{tabular}{lccccc}
\hline \multirow{2}{*}{ Jenis } & \multicolumn{5}{c}{ Komposisi Kimia (\%) } \\
\cline { 2 - 6 } & Lemak & Protein & Laktosa & Abu & Air \\
\hline Kambing & 4,09 & 3,71 & 4,20 & 0,79 & 87,81 \\
Kerbau & 7,40 & 4,74 & 4,64 & 0,78 & 82,44 \\
Kuda & 1,59 & 2,00 & 6,14 & 0,41 & 89,86 \\
Domba & 8,28 & 5,44 & 4,78 & 0,90 & 80,60 \\
Sapi & 3,9 & 3,40 & 4,80 & 0,72 & 87,10 \\
\hline
\end{tabular}

Sumber: Buckle et al., (2013)

Susu dapat dikonsumsi secara langsung, dengan catatan bahwa susu murni yang dikonsumsi terjamin higienitasnya dan keamanannya, namun lebih aman jika dikonsumsi setelah melalui perlakuan tertentu seperti pasteurisasi atau Ultra High Temperature (UHT). Selain itu, susu dapat diolah menjadi yogurt, kefir, keju, Whey Protein Isolate (WPI), Whey Protein Concentrate (WPC) dan produk berbasis susu lainnya. Produk susu dan turunannya memiliki nilai nutrisi, fungsional dan fisiologis yang bermanfaat bagi kesehatan manusia . Susu dan produk turunannya mengandung makro dan mikronutrien yang dibutuhkan oleh tubuh, nutrien yang terkandung di dalamnya termasuk protein dan peptida dan asam amino esensial (Kanekanian, 2015). Berikut ini merupakan komposisi kimia beberapa produk olahan susu disajikan pada Tabel 1:

Tabel 1. Komposisi Kimia Beberapa Mamalia

\begin{tabular}{lccccc}
\hline \multirow{2}{*}{ Jenis Olahan susu } & \multicolumn{4}{c}{ Komposisi Kimia } & \multirow{2}{*}{ Sumber } \\
\cline { 2 - 5 } & Lemak & Protein & Abu & Air & \\
\hline Yogurt Susu Sapi (\%) & 2,72 & 4,3 & 0,67 & 83,1 & Rahmawati \& Suntornsuk (2016) \\
Yogurt Susu Kambing (\%) & 2,3 & 4,7 & 0,67 & 82,3 & Rahmawati \& Suntornsuk (2016) \\
Yogurt Susu Kerbau (\%) & 5,51 & 4,7 & 0,67 & 82,04 & Rahmawati \& Suntornsuk (2016) \\
Dadih (\%) & 8,32 & 4,27 & 0,53 & 72,85 & \\
Kefir (\%) & 4,87 & 3,01 & - & 86,72 & Setyawardani (2012) \\
\hline
\end{tabular}

Susu dan produk turunannya juga memiliki beberapa sifat fisiologis. Lemak yang ada pada susu dan produk turunannya adalah asam lemak jenuh dan tidak jenuh, yang mana memiliki peran fisiologis yang penting seperti Conjugated Linoleic Acid (CLA), selain itu sus dan produk turunannya mengandung laktosa dan serta oligosakarida, vitamin, terutama vitamin yang larut dalam lemak $\mathrm{A}, \mathrm{D}$, $\mathrm{E}$ dan $\mathrm{K}$ dan beberapa vitamin yang larut dalam air seperti vitamin B12, vitamin B2 dan vitamin C. Nutrien dalam produk susu dan turunannya merupakan elemen penting untuk pertumbuhan dan pemeliharaan kesehatan tubuh (Kanekanian, 2015).

Beberapa jenis susu dan produk olahannya dapat ditambahkan probiotik, probiotik, atau ekstrak tumbuhan tertentu yang berpotensi sebagai fitokimia yang bertujuan untuk meningkatkan sifat bioaktifnya, seperti pada penelitian Wihansah et al. (2018) yogurt probiotik susu kambing yang disuplementasi dengan rosela ekstrak. Penambahan rosela ekstrak dapat meningkatkan aktivitas $\alpha$ - 
Glukosidase Inhibitor sebagai antidiabetes dengan konsentrasi penambahan rosella sebanyak 25\% mampu menghambat aktivitas $\alpha$-Glukosidase sebanyak $87,72 \%$.

\section{Beberapa Komponen Bioaktif dalam Produk Susu dan Turunannya Probiotik}

Probiotik adalah mikroorganisme hidup yang bisa bertahan melalui bagian atas pencernaan, lingkungan asam pada lambung dan melekat dan berkoloni di usus dimana dapat menyeimbangkan mikroflora dalam pencernaan. Sebagian besar probiotik adalah bakteri asam laktat yang memproduksi asam laktat sebagai produk akhir dari fermentasi karbohidrat. Bakteri Asam Laktat (BAL) yang termasuk probiotik adalah kelompok Lactobacillus, Bifidobacterium dan beberapa Streptococcus. Berikut ini merupakan manfaat probiotik: (1) memberikan keuntungan kesehatan bagi inangnya, (2) dapat menanggulangi penyakit gastroenteristis, (3) menstimulasi Sistem Imun, (4) menurunkan kolesterol, (5) mengurangi resiko kanker kolon, dan (6) mencegah dermatitis atopik pada anak (Antarini, 2011).

Probiotik bekerja dengan cara memproduksi senyawa antimikroba seperti asam laktat, asam asetat, $\mathrm{CO}_{2}, \mathrm{H}_{2} \mathrm{O}_{2}$, bakteriosin dan lain-lain. Probiotik juga unggul dalam kompetisi penyerapan nutrien dan dapat menstimulasi sistem imun. Probiotik dapat ditemukan dari pangan fermentasi yang mengandung bakteri asam laktat, walaupun tidak semua bakteri asam laktat merupakan probiotik. Beberapa contoh pangan yang mengandung probiotik diantaranya adalah yogurt, susu dan susu fermentasi. Probiotik harus aman dan dikonsumsi dengan jumlah yang cukup saat dikonsumsi. Beberapa studi klinis menguatkan efek positif dari probiotik dalam penyakit gastrointestinal seperti sindrom iritasi usus, gangguan pencernaan, pengeluaran Heliobacter, penyakit inflamasi usus, diare dan penyakit alergi seperti dematitis atopik. Selain itu, probiotik juga dapat menekan resiko obesitas, sindrom resistansi pada insulin, diabetes tipe-2 dan beberapa penyakit lainnya (Markowiak \& Ślizewska, 2017). Selama fermentasi, bakteri asam laktat memproduksi asam organik (asam laktat, asam asetat, asama sitrat dan butirat), etanol, hidrogen peroksida, karbon dioksida, diasetil, asetaldehid dan bakteriosin yang mana memiliki aktivitas antimikroba (Ouwehand \& Salminen, 1998).

\section{Prebiotik}

Prebiotik adalah non digestible food ingredient atau bahan pangan tidak dapat dicerna yang berpengaruh baik terhadap inang atau host dengan cara menstimulasi aktivitas, pertumbuhan yang selektif atau keduanya terhadap satu jenis atau lebih mikroorganisme penghuni kolon (Lee \& Salminen, 2008). Prebiotik disebut juga sebagai alternatif yang digunakan untuk probiotik atau sebagai pendukung bagi probiotik. Prebiotik dapat menstimulasi pertumbuhan bakteri pada saluran pencernaan (Markowiak \& Ślizewska, 2017).

Prebiotik biasanya merupakan karbohidrat tidak dicerna dan tidak dapat diserap dalam bentuk oligosakarida, inulin dan serat pangan. Asam lemak rantai pendek (Short Chain Fatty Acids atau disingkat SCFAs) seperti asam asetat, propionate dan asam butirat dihasilkan dari fermentasi prebiotik dalam saluran pencernaan. Karakteristik prebiotik diantaranya: 1) Tahan terhadap enzim pencernaan dalam usus manusia, 2) Difermentasi oleh koloni mikroflora dan bifidogenik dari efek $\mathrm{pH}$ rendah dan 3) Menghalangi bakteri patogen. Selain itu, ada beberapa syarat prebiotik, antara lain: 1) Tidak tercerna atau terserap pada saluran pencernaan bagian atas, 2) Secara selektif dapat menstimulir pertumbuhan bakteri yang menguntungkan pada kolon, dan 3) Menekan pertumbuhan bakteri patogen (Antarini, 2011)

Prebiotik dapat menstimulir pertumbuhan bakteri yang menguntungkan dalam usus yang mana dapat memberikan efek kesehatan seperti memperbaiki sistem imun, meningkatkan pencernaan dan penyerapan, sistesis vitamin, menekan pertumbuhan bakteri patogen dan menurunkan kolesterol darah (Gibson, 2004; Azhar, 2009). Prebiotik, salah satunya inulin dapat difermentasi dengan cepat oleh Bifidobacteria dan Lactobacilli dengan memproduksi SCFA dan L-laktat. Asam lemak rantai pendek mempengaruhi fungsi imun, kesehatan jantung dan dapat mencegah kanker serta inulin dapat meningkatkan penyerapan mineral seperti $\mathrm{Ca}, \mathrm{Mg}$ dan Fe. Selain itu juga, SCFA mampu menekan pertumbuhan bakteri patogen (Azhar, 2009)

Prebiotik diantaranya merupakan oligosakarida tidak tercerna, seperti rafinosa, fruktooligosakarida (FOS), galaktosil-laktosa, Isomatooligosakarida atau trans galaktooligosakarida (TOS). Inulin dan oligosakarida bisa diisolasi dari sumber alami seperti umbi-umbian. Prebiotik 
biasanya ditambahkan pada pangan, seperti pada produk susu bubuk (Antarini, 2011). Prebiotik secara alami juga terdapat dalam bahan pangan seperti asparagus, buah bit, bawang putih, bawang bombay, gandum, madu, tomat dan lain-lain (Davani-Davari et al., 2019). Inulin yang diisolasi dari Akar Jombang (Taraxacum officiale Webb.) diketahui dapat meningkatkan pertumbuhan bakteri $L$. bulgaricus dan Bifidobacterium (Indriyanti et al., 2015).

\section{Sinbiotik}

Sinbiotik merupakan kombinasi seimbang dari probiotik dan prebiotik yang dapat mendukung pertumbuhan bakteri yang menguntungkan dalam saluran pencernaan makhluk hidup. Jumlah sel probiotik hidup pada produk susu fermentasi dapat memberikan efek terapeutik pada $20-30 \times 10^{8} \mathrm{cfu} / \mathrm{ml}$ (Antarini, 2011). Beberapa contohnya adalah yogurt yang ditambahkan probiotik dari golongan bifidobacterium dan penambahan inulin. Probiotik dan prebiotik yang dikombinasikan dalam suatu produk diharapkan dapat memperbaiki ketahanan hidup bakteri probiotik pada saluran pencernaan, sehingga keduanya dapat menstimulasi pertumbuhan dan aktivitas bakteri eksogen (probiotik) dan bakteri endogen seperti Bifidobacteria (Ngatirah, 2009). Salah satu produk pangan sinbiotik adalah yogurt sinbiotik, pada penelitian Indriyanti et al., (2015), inulin yang diekstrak dari akar jombang dapat meningkatkan pertumbuhan bakteri Lactobacillus bulgaricus dan Bifidobacterium bifidium.

\section{Peptida Bioaktif}

Peptida bioaktif merupakan jenis peptida yang tersusun atas komposisi asam amino yang memiliki dan menunjukkan sifat-sifat spesifik. Jenis peptida bioaktif biasanya memiliki berat molekul 3 sampai 10 asam amino saja dan bersifat hidrofobik. Peptida bioaktif dihasilkan dari hidrolisis enzimatik, proses pengolahan panas (panas dan kondisi alkali) dan degradasi proteolitik oleh mikroorganisme. Peptida bioaktif telah diidentifikasi dalam asam amino yang ada dalam protein susu. Secara fisiologis dan fisiko-kimia, peptida susu merupakan bahan yang baik untuk meningkatkan status kesehatan (Park \& Nam, 2015). Contohnya Peptida susu Laktoferin B dan Lactoferin (f 17-41) yang dapat dikatalisis oleh pepsin dan memiliki kemampuan sebagai antimikroba (Mohanty et al., 2016).

Peptida bioaktif yang diperoleh dari kasein susu kambing dengan fraksi peptida dengan berat molekul <30 kDa, menunjukkan aktivitas antibakteri terhadap Staphylococcus aureus (Lestari \& Giordan, 2020). Selain itu, peptida bioaktif yang diisolasi dari $\beta$-kasein susu kambing dengan susunan asam amino Ile-Asp-Lys (INK) memiliki kemampuan dalam menghambat kinerja ACE yang dikenal sebagai ACE inhibitor (Widodo et al., 2019).

\section{Conjugated Linoleic Acid (CLA)}

Conjugated Linoleic Acid (CLA), Linoleat (omega-6) dan linolenat terkonjugasi banyak ditemukan di pangan yang berasal dari hewan. Fungsi CLA secara umum menurunkan kadar kolesterol sehingga berperan dalam mencegah dan mengobati penyakit yang berhubungan dengan penyakit kardiovaskular. CLA ditemukan secara alami dalam lemak hewan ruminansia dan produk susu dan turunannya. CLA berfungsi sebagai antikanker dan antiaterogenik. Salah satu produk susu yang dapat berpotensi dalam menurunkan kadar trigliserida adalah kefir yang mana mengandung CLA. CLA merupakan hasil metabolit dari susu fermentasi, CLA diduga dapat meningkatkan lipolisis dan beta oksidasi asam lemak sehingga pembentukan trigliserida dapat dikurangi (Putri Sari \& Pramono, 2012). Berikut ini merupakan beberapa penelitian mengenai pangan fungsional berbasis susu dapat dilihat pada Tabel 3. 
Journal of Surimi (Sustainable Research In Management of Agroindustry)

Vol 01 No. 01 April (2021) / Suciati dan Safitri

https://doi.org/10.35970/surimi.v1i1.535

Tabel 3. Beberapa Penelitian Pangan Fungsional Berbasis Susu

\begin{tabular}{|c|c|c|c|c|c|}
\hline $\begin{array}{c}\text { Jenis Susu dan Produk } \\
\text { Olahannya } \\
\end{array}$ & Probiotik/Prebiotik & Komponen bioaktif & Susunan Asam Amino & Fungsi Fisiologis & Sumber \\
\hline Dadih & - & Peptida bioaktif & Thr-Pro-Ala-Phe-Glu & ACE-Inhibitor & Chalid et al. (2018) \\
\hline Susu unta fermentasi & $\begin{array}{l}\text { L. lactis KX881782 L. } \\
\text { achidophilus DSM9126 }\end{array}$ & Peptida bioaktif & - & $\begin{array}{l}\text { Antioksidan, } \\
\text { antidiabetik, ACE- } \\
\text { inhibitor dan } \\
\text { antiproliferatif }\end{array}$ & Ayyash et al., (2018) \\
\hline Susu sapi fermentasi & $\begin{array}{l}\text { L. lactis KX881782 L. } \\
\text { achidophilus DSM9126 }\end{array}$ & Peptida bioaktif & - & $\begin{array}{l}\text { Antioksidan, } \\
\text { antidiabetik, ACE- } \\
\text { inhibitor dan } \\
\text { antiproliferatif }\end{array}$ & Ayyash et al., (2018) \\
\hline Susu Kambing (Kasein $\beta$ ) & - & Peptida bioaktif & Ile-Asp-Lys & ACE-Inhibitor & Widodo et al., (2019) \\
\hline Yogurt susu kambing & & Peptida bioaktif & $\begin{array}{l}\text { LYQEPVLGPVRGPFPI } \\
\text { YQEPVLGPVRGPFPIL }\end{array}$ & Antioksidan & Mahdi et al., (2018) \\
\hline Yogurt Sinbiotik & $\begin{array}{c}\text { L. acidophilus, L. casei dan } \\
\text { L. paracasei }+ \text { PPP } \\
\text { (Pineapple Peel Powder) }\end{array}$ & Peptida bioaktif & VQSWMHQPPQPLSPT & $\begin{array}{c}\text { Antibakteri dan } \\
\text { Antiproliferatif terhadap } \\
\text { sel kanker HT29 }\end{array}$ & Sah et al., (2016) \\
\hline Yogurt Probiotik Susu Kambing & L. acidophilus IIA-2B4 & Peptida bioaktif & - & $\begin{array}{l}\alpha \text {-Glukosidase Inhibitor } \\
\text { (Antidiabetes) }\end{array}$ & Wihansah et al., (2018) \\
\hline
\end{tabular}




\section{Kesimpulan}

Susu dan produk turunannya sangat potensial untuk dikembangkan menjadi pangan fungsional. Bioaktif peptida, prebiotik, probiotik, CLA dan beberapa komponen lainnya dapat memberikan pengaruh positif terhadap kesehatan tubuh. Pangan fungsional berbasis susu secara signifikan dapat berkontribusi dalam pencegahan penyakit seperti hipertensi, kanker, diabetes dan penyakit degeneratif lainnya. Selain itu, pangan fungsional berbasis susu juga dapat memberikan pengaruh positif terhadap sistem pencernaan yang selanjutnya dapat meningkatkan sistem imun.

\section{Daftar Pustaka}

Afriani. (2012). Kualitas dan Aktivitas Antimikroba Produk Dadih Susu Sapi pada Penyimpanan Rendah. Agrinak, 02(1), 11-16.

Antarini, A. A. N. (2011). Sinbiotik Antara Prebiotik dan Probiotik. Jurnal Ilmu Gizi, 2(2), 148-155.

Ayyash, M., Al-dhaheri, A. S., Mahadin, S. Al, Kizhakkayil, J., \& Abushelaibi, A. (2018). In vitro investigation of anticancer, antihypertensive, antidiabetic, and antioxidant activities of camel milk fermented with camel milk probiotic: A comparative study with fermented bovine milk. Journal of Dairy Science, 101(2), 900-911. https://doi.org/10.3168/jds.2017-13400

Azhar, M. (2009). Inulin sebagai prebiotik. SAINSTEK, 12(1), 8.

Azura, A. R., Diantini, A., Farmasi, F., \& Padjadjaran, U. (2019). Farmaka Farmaka. 17, 209-221.

BPOM. (2005). Peraturan Kepala BPOM RI nomor HK 00.05.52.0685. Peraturan Kepala Badan Pengawas Obat Dan Makanan Republik Indonesia, 1-13.

Buckle, K. A. ., Edwards, R. A. ., Fleet, G. H. ., \& Wootton, M. . (2013). Ilmu Pangan. UI-Press.

Chalid, S. R. I. Y., Nurbayti, S., \& Pratama, A. F. (2018). Karakterisasi dan Uji Aktivitas Protein Susu Kerbau (Bubalus bubalis ) Fermentasi sebagai Angiotension Converting Enzyme ( ACE ) Inhibitor ( Characterization and Angiotension Converting Enzyme ACE-inhibitory activity of Fermented Buffalo Milk ( Bubalus b. 16(2), 214-224.

Davani-Davari, D., Negahdaripour, M., Karimzadeh, I., Seifan, M., Mohkam, M., Masoumi, S. J., Berenjian, A., \& Ghasemi, Y. (2019). Prebiotics: Definition, types, sources, mechanisms, and clinical applications. Foods, 8(3). https://doi.org/10.3390/foods8030092

European Commisson. (2010). Functional foods. In European Union. Publications Office of the European Union. https://doi.org/10.1016/S0140-6736(99)80007-5

Indriyanti, W., Desvianto, R., Musfiroh, I., Farmasi, F., Padjadjaran, U., \& Barat, J. (2015). Inulin dari Akar Jombang ( Taraxacum officinale Webb .) sebagai Prebiotik dalam Yoghurt Sinbiotik Inulin from Jombang Root ( Taraxacum officinale Webb .) as Prebiotic in Synbiotic Yoghurt. 2.

Kanekanian, A. (2015). The Health Benefits of Bioactive Peptide Compounds from Milk and Dairy Products. In A. Kanekanian (Ed.), Functional dairy foods and ingredients. (pp. 1-18). John Wiley $\&$ Sons, Ltd.

Kementerian Pertanian. (2019). Buku Outlook Komoditas Peternakan Susu Sapi. In book (Issue ISSN 1907-1507).

Lee, Y. K., \& Salminen, S. (2008). Handbook of Probiotics and Prebiotics: Second Edition. John Wiley \& Sons, Inc. https://doi.org/10.1002/9780470432624

Lestari, D., \& Giordan, E. (2020). Peptida Bioaktif Kasein Susu Kambing sebagai Agen Antibakteri terhadap Staphylococcus aureus Peptida Bioaktif Kasein Susu Kambing sebagai Agen Antibakteri terhadap Casein Goat's Milk Bioactive Peptides as Antibacterial Agent Against. April. https://doi.org/10.30997/jah.v6i1.2025

Mahdi, C., Untari, H., \& Padaga, M. C. (2018). Identification and Characterization of Bioactive Peptides of Fermented Goat Milk as a Sources of Antioxidant as a Therapeutic Natural Product Identification and Characterization of Bioactive Peptides of Fermented Goat Milk as a Sources of Antioxidant as a. https://doi.org/10.1088/1757-899X/299/1/012014

Markowiak, P., \& Ślizewska, K. (2017). Effects of probiotics, prebiotics, and synbiotics on human health. Nutrients, 9(9). https://doi.org/10.3390/nu9091021

Mohanty, D. P., Mohapatra, S., Misra, S., \& Sahu, P. S. (2016). Milk derived bioactive peptides and their impact on human health - A review. Saudi Journal of Biological Sciences, 23(5), 577-583. https://doi.org/10.1016/j.sjbs.2015.06.005 
Ngatirah. (2009). Probiotik, Prebiotik dan Sinbiotik. Agroteknose, IV(2), 46-48.

Ouwehand, A. C., \& Salminen, S. J. (1998). The health effects of cultured milk products with viable and non-viable bacteria. International Dairy Journal, 8(9), 749-758. https://doi.org/10.1016/S0958-6946(98)00114-9

Park, Y. W., \& Nam, M. S. (2015). Bioactive Peptides in Milk and Dairy Products: A Review Functionalities of Bioactive Peptides. 35(6), 831-840.

Playne, M. J., Bennett, L. E., \& Smithers, G. W. (2003). Functional dairy foods and ingredients. Australian Journal of Dairy Technology, 58(3), 242-264.

Putri Sari, F. N., \& Pramono, A. (2012). Pengaruh Pemberian Kefir Susu Sapi Terhadap Kadar Trigliserida Tikus Jantan Sprague Dawley. Journal of Nutrition College, 1(1), 322-326. https://doi.org/10.14710/jnc.v1i1.724

Rahmawati, I. S., \& Suntornsuk, W. (2016). Effects of Fermentation and Storage on Bioactive Activities in Milks and Yoghurts. 18(Mcls 2015), 53-62. https://doi.org/10.1016/j.proche.2016.01.010

Sah, B. N. P., Vasiljevic, T., Mckechnie, S., \& Donkor, O. N. (2016). Antibacterial and antiproliferative peptides in synbiotic yogurt - Release and stability during refrigerated storage. 4233-4242. https://doi.org/10.3168/jds.2015-10499

Setyawardani, T., Sumarmono, J., Arief, I. I., Hantoro, A., Rahardjo, D., Widayaka, K., \& Santosa, S. S. (2020). Improving composition and microbiological characteristics of milk kefir using colostrum. 2061.

Widodo, H. S., Mada, U. G., Murti, T., Mada, U. G., Agus, A., Mada, U. G., \& Performance, G. (2019). Mengidentifikasi Peptida Bioaktif Angiotensin Converting Enzyme-inhibitor Mengidentifikasi Peptida Bioaktif Angiotensin Converting Enzyme- inhibitor ( ACEi ) dari Kasein $\beta$ Susu Kambing dengan Polimorfismenya Melalui Teknik In Silico. January. https://doi.org/10.17728/jatp.3008

Wihansah, R. R. S., Arief, I. I., \& Batubara, I. (2018). Anti-diabetic Potency and Characteristics of Probiotic Goat-Milk Yogurt Supplemented with Roselle Extract during Cold Storage. December, 191-199. 